\title{
Revisiting China's Exchange Rate Regime and RMB Basket: A Recent Empirical Study
}

\author{
Yuming Cui ${ }^{1}$ \\ ${ }^{1}$ Graduate School of Asia-Pacific Studies, Waseda University, Tokyo, Japan \\ Correspondence: Yuming Cui, Graduate School of Asia-Pacific Studies, Waseda University, Nishi-Waseda \\ Bldg.7F, 1-21-1 Nishi-Waseda, Shinjyuku-ku, Tokyo, 169-0051, Japan. Tel: 80-3303-1308. E-mail: \\ cuiyuming@fuji.waseda.jp
}

Received: November 18, 2013

Accepted: December 5, 2013 Online Published: January 23, 2014

doi:10.5539/ijef.v6n2p150

URL: http://dx.doi.org/10.5539/ijef.v6n2p150

\begin{abstract}
China announced to adopt managed floating exchange rate regime with reference to a basket of currencies in July 2005, but did not unveil exact weight of each of component currencies in RMB basket. We attempt to find the latest evidence on how the RMB pegs to its currency basket. This research begins with a short review of the evolutionary history of the RMB exchange rate regime in different periods from 1949 to 2013. We then move forward to examine how the RMB pegs to its currency basket and estimate the weight of each of component currencies over the period from January 2007 to March 2013 by applying Frankel and Wei (1994)'s model. The results illustrate that the RMB did not perfectly peg to RMB basket as the PBoC announced during the period from January 2007 to March 2013. But we find the US dollar's weight has declined steadily since 2011, although it still is the most important reference currency to peg for the RMB. Interestingly, other currencies like Singapore dollar received increasing weight in RMB basket. It implies that RMB exchange rate regime is in the transitional period from single currency peg to currency basket peg.
\end{abstract}

Keywords: China, RMB, exchange rate regime, currency basket

\section{Introduction}

Exchange rate policy has become one of the key global economic issues when cooperation on protesting trade protectionism and stabilizing global economy among countries seriously weakened since Global Financial Crisis 2007-2008. During the period of financial crisis and in the aftermath, the US's monetary authority pumped liquidity to stimulate economic growth which is known as QE1, 2 and 3. The US dollar depreciated considerably against the major emerging economies' currencies. Some East Asian emerging countries struggled to avoid currency appreciation in order to keep export competitiveness advantage. International community deeply concerned the "Currency War" (Note 1) when some governments attempted to use exchange rate policy as a tool to keep export competitiveness and economic growth. More recently, Japan's easing monetary policy adopted by Abe administration evoked lively debate on the impact of one country's exchange rate policy on other countries (Note 2).

Among many arguments on exchange rate policy in the world, Chinese currency, renminbi (also called yuan, henceforth the RMB) and China's exchange rate policy are on the central stage. The RMB suffered increasing pressure economically and politically from the international community, especially from the United States. Since China announced to adopt new exchange rate regime which is shifting from pegging to the US dollar toward pegging to a basket of currencies in July 2005, and reconfirmed to reform the RMB exchange rate regime and enhance RMB exchange rate flexibility in June 2010, it seems that rest of world still doubted if China's authority has actually adopted this currency basket peg regime and to what extent China implemented it.

There is a large body of research on the RMB's currency basket (Frankel, 1993; Frankel \& Wei, 1994, 2007, 2008; Shah et al., 2005; Eichengreen, 2006; Yamazaki, 2006). Their results show that there are signs that RMB exchange rate regime is moving away from the US dollar peg, but not significantly. It is interesting to know what recent RMB exchange rate regime is, in particular, after June 2010 when the new policy was announced by People's Bank of China (the PBoC). In this study, we revisit China's exchange rate policy and currency basket of the RMB. To do that, firstly, we review the evolutionary history of RMB exchange rate regime from 1949 to 2012 . We then move forward to analyze how the RMB pegs to its currency basket and estimate the weight of each of component 
currencies by applying Frankel and Wei (1994)'s model. To avoid repeating the works have been done by previous studies, we examine RMB basket in the period which has never been covered in previous studies. Also, we compare our results with the findings in previous studies in order to find recent changes of RMB exchange rate regime.

The reset paper is organized as follows. We briefly review the evolutionary history of RMB exchange rate regime from 1949 to 2013 and introduce the RMB's currency basket in section Two. Section Three presents the data and economic model we apply in the paper. Empirical results are analyzed in section Four. Section Five concludes the paper.

\section{RMB Exchange Rate Regime and RMB Basket}

\subsection{Evolutionary History of RMB Exchange Rate Regime}

Compared to other major currencies, the RMB's 64 years history is relatively short. But it has experienced significant adjustments due to economic and political reasons (see Figure 1). It is widely accepted that the history of RMB exchange rate regime can be divided into four periods according to RMB exchange rate policies announced by the PBoC (Sun et al., 2008; Qin, 2010). Table 1 shows the summary of various RMB exchange rate polices in four periods from 1949 to 2012 . Since 2005, China moved into a managed floating exchange rate regime based on market supply and demand with reference to a basket of currencies, which was officially announced by the PBoC on July 21, 2005. In addition, the daily trading band of RMB exchange rate in inter-bank exchange market was set at \pm 0.3 per cent in bilateral exchange rate between the RMB and the US dollar, which was widened to \pm 0.5 per cent on May 21, 2007 and \pm 1.0 per cent on April 14, 2012. It was looked as a positive signal that China realized the importance of RMB exchange rate regime reform and would accelerate this process. Since then, the reform of the RMB exchange rate regime has been made significant progress and RMB exchange rate policy as a policy instrument started play more important role in China's economic development, in particular, China's foreign trade growth.

Table 1. Summary of RMB exchange rate regime from 1949-2012

\begin{tabular}{|c|c|c|c|}
\hline Stage & Period & $\begin{array}{l}\text { Target of RMB exchange } \\
\text { rate policy }\end{array}$ & $\begin{array}{c}\text { Characteristics of } \\
\text { RMB exchange rate }\end{array}$ \\
\hline $\begin{array}{l}\text { National economy } \\
\text { recovery period }\end{array}$ & $\begin{array}{r}1949-1950 \\
1951-1952\end{array}$ & $\begin{array}{l}\text { encouraging exports and constraining } \\
\text { imports } \\
\text { balancing between imports and } \\
\text { exports }\end{array}$ & $\begin{array}{l}\text { fluctuated dramatically and changed frequently; changed } \\
\text { from multiple exchange rates into united exchange rate. } \\
\text { rallied gradually; transferred from "encouraging exports } \\
\text { and constraining imports" into "balancing between imports } \\
\text { and exports". }\end{array}$ \\
\hline $\begin{array}{l}\text { Command economy } \\
\text { period }\end{array}$ & $\begin{array}{r}1953-1972 \\
1973-1980\end{array}$ & $\begin{array}{l}\text { relatively fixed exchange rate regime } \\
\text { pegging to a currency basket }\end{array}$ & $\begin{array}{l}\text { kept stable; ineffective as an economic tool to modulate } \\
\text { China's economic development. } \\
\text { fluctuated frequently; seriously overvalued. }\end{array}$ \\
\hline $\begin{array}{l}\text { Economy transition } \\
\text { period }\end{array}$ & $\begin{array}{r}1981-1984 \\
1985-1993\end{array}$ & $\begin{array}{l}\text { dual RMB exchange rate regime } \\
\text { canceled ISR, but actually } \\
\text { implemented dual exchange rate } \\
\text { regime again }\end{array}$ & $\begin{array}{l}\text { two exchange rates existed simultaneously: official } \\
\text { exchange rate and RMB Internal Settlement rate (ISR). } \\
\text { frequently adjusted; depreciated sharply; Foreign } \\
\text { Exchange Swap Centers (FESC) was established. }\end{array}$ \\
\hline $\begin{array}{l}\text { Market mechanism } \\
\text { period }\end{array}$ & 1994-2005 & $\begin{array}{l}\text { managed floating exchange rate } \\
\text { regime based on market supply and } \\
\text { demand with reference to a currency } \\
\text { basket }\end{array}$ & $\begin{array}{l}\text { foreign exchange surrender system was launched; RMB } \\
\text { official exchange rate depreciated in one-step sharply; de } \\
\text { facto pegged to the US dollar since } 1997 \text { Asia Financial } \\
\text { Crisis until } 2005 \text {. } \\
\text { appreciated gradually; widened daily movement band from } \\
\pm 0.3 \% \text { to } \pm 0.5 \%, \pm 1.0 \% \text {; under pressure internally and } \\
\text { externally to allow RMB appreciation further. }\end{array}$ \\
\hline
\end{tabular}




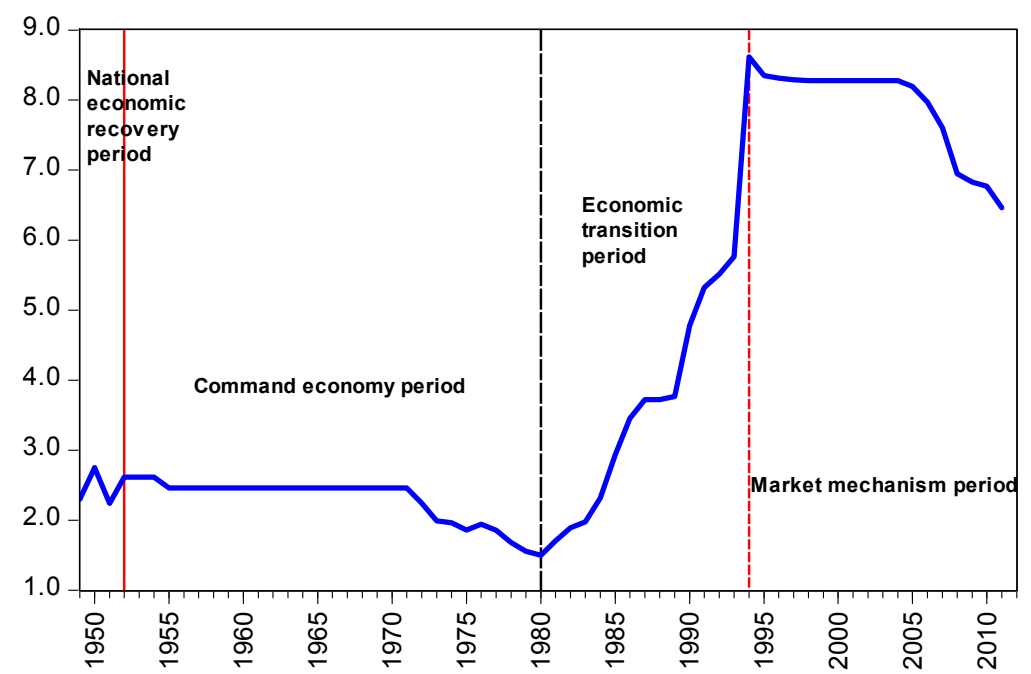

Figure 1. RMB nominal exchange rate, against the US dollar, yearly, 1949-2012

Source: China Statistics Yearbooks (1995-2012).

However, the Global Financial Crisis 2007-2008 disrupted China's exchange rate regime reform. China returned to peg the RMB to the US dollar in the midst of financial crisis (see Figure 1). Such policy reversion led to critics from the rest of the world. On June 19, 2010, the PBoC announced that China would proceed to reform the RMB exchange rate regime and enhance the RMB exchange rate flexibility (Note 3), which implies that China would continue the process of RMB exchange rate reform. From June of 2010, the RMB restarted to be revaluated gradually. The RMB in nominal term appreciated at 3-4 per cent of annual rate since 2005. Meanwhile, the real effective exchange rate (REER) of the RMB also increased considerably by 29 per cent by the end of 2012 , although it dropped in 2009 (see Figure 2).
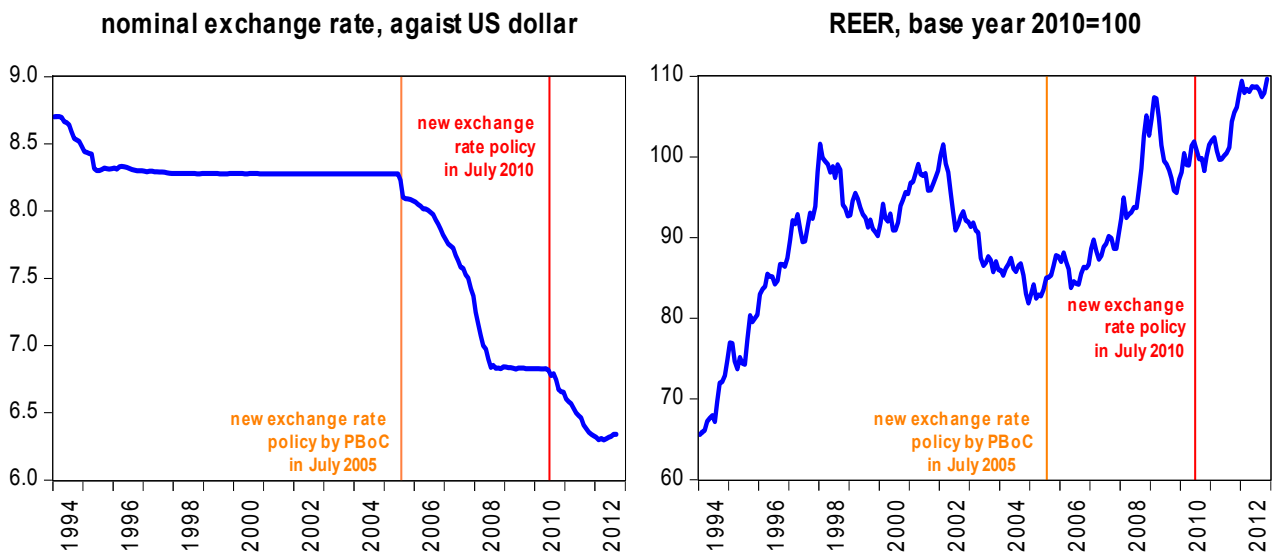

Figure 2. RMB nominal exchange rate and the REER, 1994-2012

Source: the PBoC and BIS.

Generally speaking, China has successfully managed RMB exchange rate policy which contributed to China's economic growth significantly. Especially, since 2005 when China changed single currency peg into a currency basket peg regime, China's exports and economic growth continued to grow without damaging China's international competitiveness. As an integral component of China's ongoing financial system reform, the goal of RMB exchange rate regime reform is achieving free floating exchange rate regime. Meanwhile, mounting external pressure on the RMB's value and deepening global financial system reform under G20 framework push China's authority to continue RMB exchange rate formation mechanism reform. How to smoothly push forward RMB exchange rate regime reform is still a challenging task for China's authority. Now China's RMB exchange rate regime is at the crossroad (Obstfeld, 2007). 
In this research, given the drastic adjustment in RMB exchange rate regime since 2005, particularly in the aftermath of recent global financial crisis, we are interested in answering the following questions about RMB exchange rate regime: What is exchange rate regime China's authority is adopting actually now? Is it a real managed floating exchange rate regime with reference to a basket of currencies? If so, to what extent the RMB is pegging to its currency basket? To solve these questions, now we move forward to analyze the RMB's currency basket.

\subsection{The RMB's Currency Basket}

Since the PBoC officially announced to adopt managed floating exchange rate regime by pegging to a currency basket rather than pegging to the US dollar in July 2005, it has never officially revealed the information about composition of RMB basket and weight of each of component currencies. But Zhou Xiaochuan, the governor of PBoC, released a little information about the RMB's basket of currencies in 2005 (Note 4). According to Zhou, the selection principle of candidate currencies is referring to the weights of foreign exchanges which were frequently used in China's foreign trade settlement. Based on this principle, the main currencies in RMB basket are the US dollar, the euro, Japanese yen, and Korean won. Furthermore, Singaporean dollar, British pound sterling, Malaysian ringgit, Australian dollar, Canadian dollar, Russian ruble and Thai baht are also important reference currencies in RMB basket. But the weights of each component currency in RMB basket and frequency of weights adjustment remained unclear. Table 2 shows the component currencies which may be included in RMB basket according to Zhou (2005).

Table 2. Component currencies in currency basket of the RMB

\begin{tabular}{|c|c|c|}
\hline Currencies & Name & Symbol \\
\hline \multirow{4}{*}{$\begin{array}{l}\text { Main Currencies } \\
\quad \text { (first tier) }\end{array}$} & The US Dollar & USD \\
\hline & The Euro & EUR \\
\hline & Japanese Yen & JPY \\
\hline & Korean Won & KRW \\
\hline \multirow{7}{*}{$\begin{array}{l}\text { Other Currencies } \\
\text { (second tier) }\end{array}$} & Singaporean Dollar & SGD \\
\hline & British Pound & GBP \\
\hline & Malaysian Ringgit & MYR \\
\hline & Australian Dollar & AUD \\
\hline & Canadian Dollar & CAD \\
\hline & Russian Ruble & RUB \\
\hline & Thai Baht & THB \\
\hline
\end{tabular}

Source: according to the PBoC governor's public speech on August 9, 2005.

\section{Date and Methodology}

\subsection{Data}

Since similar studies about RMB basket have been done in previous studies (Frankel \& Wei, 1994, 2007; Yamazaki, 2006), in this research we examine RMB basket by covering the period which has not been tested in previous studies. The latest research on RMB basket using the same model we use in this research is done by Frankel and Wei (2007). The period they cover is from July 2005 to August 2007 (Note 5). In this paper, by using the same model, we examine RMB basket covering the period from January 2007 to March 2013 to find the latest evidence on the RMB's currency basket pegging regime. It is notable that during the recent global financial crisis, the RMB appeared to be heavily pegged to the US dollar from mid-2008 to mid-2010. We can see from Figure 3 that RMB nominal exchange rate against the US dollar kept relatively unchanged for about two years from July 2008 to June 2010. Therefore, we divide whole sample period into three periods: period 1 (pre-crisis): January 1, 2007-June 30, 2008; period 2 (period of crisis): July 1, 2008-June 30, 2010 and period 3 (post-crisis): July 1, 2010-March 30, 2013 (see Figure 3). By doing so, we could not only find changes of the RMB's currency basket pegging regime before and after financial crisis, but also test if the RMB pegged to the US dollar during the period of financial crisis. In addition, due to applying the same model, we can compare our results with Frankel and Wei (2007)'s findings. 


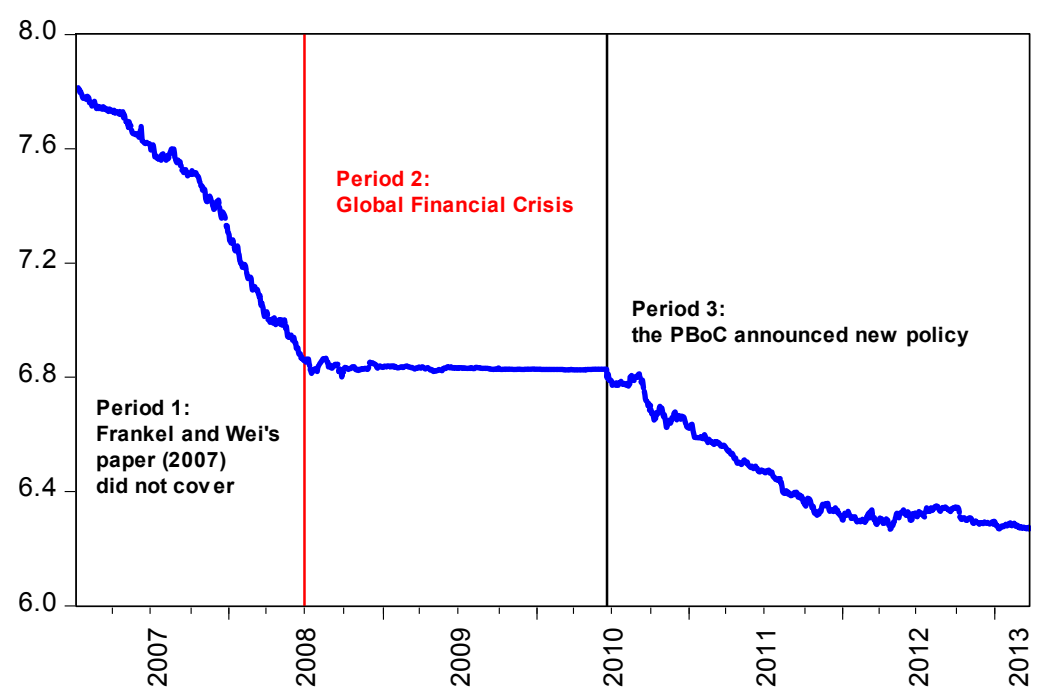

Figure 3. The RMB nominal exchange rate, against the US dollar (January 1, 2007 to March 31, 2013)

Source: State Administration of Foreign Exchange (SAFE), China.

What's more, since the PBoC reaffirmed that China would proceed to reform the RMB exchange rate regime and enhance the flexibility of RMB exchange rate in June 2010, it seemed that the RMB revaluation was accelerated. Since then, the RMB has appreciated considerably in nominal and real term. As Figure 4 shows, daily percentage change of RMB exchange rate against the US dollar is about 0.1 per cent before the global financial crisis. During the period of financial crisis, RMB exchange rate remained almost unchanged. Since the third quarter of 2010 , fluctuation of daily RMB exchange rate intensified. Its daily movement frequently reached about $0.2 \%$ after July 2010. Larger daily movement of RMB exchange rate against the US dollar since July 2010 implies that flexibility of RMB exchange rate regime was much higher than before. It clearly shows us that the RMB is no longer purely peg to the US dollar.

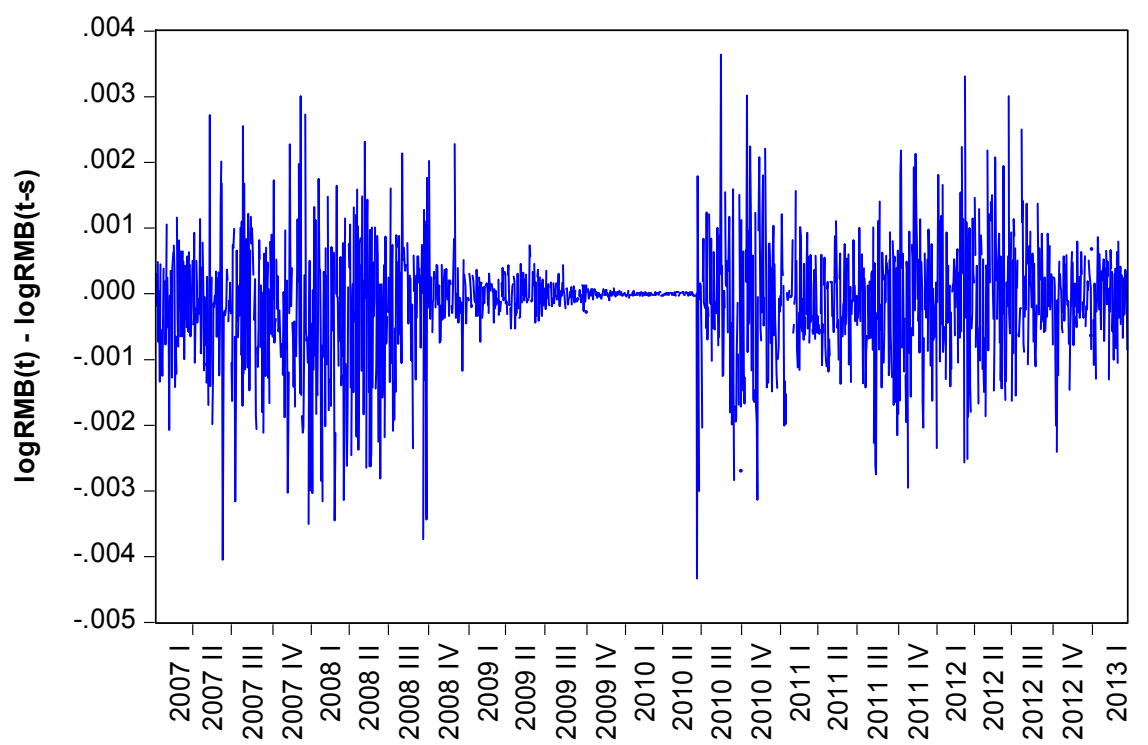

Figure 4. Changes in RMB exchange rate against the US dollar (January 1, 2007 to March 31, 2013)

Source: Author's calculation.

To find more detailed information on the RMB's currency basket pegging regime, we further divide the period 3 (33 months) into 6 sub-periods: sub-period 1: July 1, 2010 to December 31, 2010; sub-period 2: January 1, 2011 to June 30, 2011; sub-period 3: July 1, 2011 to December 31, 2011; sub-period 4: January 1, 2012 to June 30, 2012; 
sub-period 5: July 1, 2012 to December 31, 2012; sub-period 6: January 1, 2013 to March 31, 2013. Each of sub-periods is six-month long except for the last sub-period (3 months). By doing so, we could find more detailed evidence that how the RMB pegs to its currency basket and implicit weight of each of component currencies in each sub-period. For comparison, we use SDR (Special Drawing Right) (Note 6) as numeraire to define the "value" of each of component currencies in RMB basket as Frankel and Wei (2007) did (Note 7). Compared to other potential numeraire, like gold and Swiss franc, SDR is more appropriate to currency weight inference model (Frankel and Wei (1994)'s model) partly because SDR is a weighted IMF unit based on a currency basket of four major currencies in the world. Value change of each currency measured by major currencies reflects change of this currency compared to others. Therefore, SDR is the optimal numeraire to catch clues that to what extent that the RMB pegs to its currency basket. The IMF reports the daily exchange rate of all currencies against SDR.

\subsection{Methodology}

We employ the currency basket inference model developed by Frankel and Wei (1994) to examine the currency basket of the RMB. This is a well known model which was applied by Shah et al. (2005), Eichengreen (2006), Yamazaki (2006), Frankel and Wei (2007) in analyzing the RMB's currency basket. More recently, Frankel (2009) upgrade this model by adding a new variable, called Exchange Market Pressure variable which is defined as the percentage increase in the value of currency plus the increase in reserves, to re-estimate the RMB's currency basket. This upgraded model helps to capture the extent of flexibility of RMB exchange rate. Higher coefficient of this variable should lead higher floating degree because there is less external intervention in foreign exchange market. Zero means that RMB exchange rate is purely fixed while one indicates purely floating exchange rate regime. According to his result, there was an upward trend on this coefficient although it's not very significant. It increased from 0.123 in December 2008 to 0.249 in May 2009. It implies that the RMB pegged to a currency basket in an increasing extent rather than only the US dollar. Moreover, the euro and Japanese yen's weights grew during the period from July 2006 to May 2008.

Based on Frankel (2009)'s findings, in this paper, we will not add this new variable (Exchange Market Pressure variable) into Frankel and Wei (1994)'s model. We assume that the RMB pegs to its currency basket which constitutes eleven currencies more heavily than before, especially considering that the PBoC reaffirmed to proceed to reform the RMB exchange rate regime and enhance the RMB exchange rate flexibility in June 2010. Recent considerable appreciation of the RMB in nominal and real term suggests that the RMB is moving away from single currency peg (the US dollar), although it remained unclear if it actually pegs to a currency basket. Because we cannot ensure that the RMB is fully pegging to a currency basket, constant $c$ is included to allow the possibility of RMB not perfectly pegging to its currency basket. Also $c$ could measure the trend of RMB exchange rate. Therefore, we have

$$
\log R M B(t+s)-\log R M B(t)=c+\sum w(j)[\log X(j, t+s)-\log X(j, t)]
$$

where $\boldsymbol{X}$ denotes the currencies which are eleven possible component currencies in RMB basket declared by the $\mathrm{PBoC}, \boldsymbol{w}$ represents weight of each currency, $\boldsymbol{j}$ is each of currency and $\boldsymbol{c}$ is constant. If one currency purely pegs to another currency, weight $(\boldsymbol{w})$ of this reference currency should be one. If one currency perfectly pegs to a currency basket, the weights of these component currencies in its currency basket should be significant and positive. To estimate the RMB's currency basket, we assume that all eleven component currencies are included in the RMB basket.

\section{Result Analysis}

The currency weight inference model which regress the changes in the log value of RMB against the changes in the log value of eleven component currencies in RMB basket is simple and neat. The reason of choosing the change rather than the level is non-stationary data concern (Frankel and Wei, 1994). Exchange rate data is very typical time series data. It was proved that some time series data is non-stationary. So we cannot simply make a regression on two or more time series data without testing if unit root [I(1)] exists (Engel \& Granger, 1987). Table 3 shows the first difference of $\log$ value of each variable is stationary. 
Table 3. Unit root test

\begin{tabular}{ccccc}
\hline $\begin{array}{c}\text { Variables (first differences } \\
\text { in the log) }\end{array}$ & ADF test & $1 \%$ & $5 \%$ & I $(1)$ or I $(0)$ \\
\hline CNY & -39.380 & -3.435 & -2.863 & I $(0)$ \\
USD & -133.551 & -3.434 & -2.863 & I $(0)$ \\
EUR & -51.316 & -3.434 & -2.863 & I $(0)$ \\
JPY & -39.988 & -3.435 & -2.863 & I $(0)$ \\
KRW & -781.930 & -3.435 & -2.863 & I $(0)$ \\
SGD & -47.234 & -3.435 & -2.863 & I $(0)$ \\
GBP & -62.324 & -3.434 & -2.863 & I $(0)$ \\
MYR & -41.438 & -3.435 & -2.863 & I $(0)$ \\
AUD & -41.880 & -3.435 & -2.863 & I $(0)$ \\
CAD & -85.376 & -3.435 & -2.863 & I $(0)$ \\
RUB & -37.547 & -3.435 & -2.863 & I $(0)$ \\
THB & -40.178 & -3.435 & -2.864 & I $(0)$ \\
\hline
\end{tabular}

Source: author's calculation.

The results are reported in Table 4. We can see that weights of the US dollar, Japanese yen, Singaporean dollar and Russian ruble are statistically significant and positive for the whole sample. The US dollar receives the largest weight which is 86.1 per cent in RMB basket. Surprisingly, weight of Japanese yen (1.5\%) is less than this of Singaporean dollar (5.7\%), although the yen was classified into the first tier currency in RMB basket. We also notice that adjusted R-squared for the whole sample is relatively high (0.937) which implies that a tight peg of the $\mathrm{RMB}$ to its basket. In period 1 which is the period before financial crisis, more currencies in RMB basket received weights: the US dollar (83.3\%), the euro (6.3\%), Japanese yen (6.7\%), Korean won (5.1\%), Australian dollar $(3.7 \%)$ and Russian ruble (1.3\%). It suggests that the RMB pegged to its currency basket with a certain degree during this period. However, in period 2 which covers the period of financial crisis, the US dollar's weight increased sharply to 90 per cent from 83.3 per cent in previous period. Other three currencies (Japanese yen, Singaporean dollar and Thai baht) have positive and statistically significant weights, but very little. Adjusted $\mathrm{R}$-squared in period 2 is 0.98 which is very high. It indicates that the RMB exchange rate regime in financial crisis period is pegging the US dollar regime. It is consistent with the phenomenon that RMB exchange rate against the US dollar remained unchanged during the period of crisis (see Figure 4). Since July 2010 (in the period 3) when the $\mathrm{PBoC}$ reaffirmed to reform the RMB exchange rate regime, the US dollar's weight dropped to 80.2 per cent. Weights of Singaporean dollar and Russian ruble are 5.2 and 1.9 per cent, respectively.

Table 4. Estimation of eleven component currencies' weights in RMB basket (January 1, 2007 to March 31, 2013, numeraire currency $=\mathrm{SDR}$ )

\begin{tabular}{|c|c|c|c|c|c|c|c|c|}
\hline \multirow{3}{*}{$\begin{array}{l}\text { Sub-period } \\
\text { US dollar } \\
\text { the euro }\end{array}$} & \multicolumn{2}{|c|}{ Whole sample } & \multicolumn{2}{|c|}{ Period 1} & \multicolumn{2}{|c|}{ Period 2} & \multicolumn{2}{|c|}{ Period 3} \\
\hline & $0.861 * *$ & $(0.017)$ & $0.833 * *$ & $(0.052)$ & $0.901 * *$ & $(0.021)$ & $0.802 * *$ & $(0.027)$ \\
\hline & -0.002 & $(0.011)$ & $0.063^{*}$ & $(0.037)$ & 0.000 & $(0.011)$ & $-0.027 *$ & $(0.017)$ \\
\hline Japanese yen & $0.015 * *$ & $(0.005)$ & $0.067 * *$ & $(0.014)$ & $0.010^{*}$ & $(0.005)$ & 0.003 & $(0.008)$ \\
\hline Korean won & 0.005 & $(0.003)$ & $0.051 * *$ & $(0.014)$ & -0.001 & $(0.003)$ & 0.007 & $(0.009)$ \\
\hline Singapore dollar & $0.057 * *$ & $(0.016)$ & 0.025 & $(0.045)$ & $0.049 * *$ & $(0.018)$ & $0.052 * *$ & $(0.025)$ \\
\hline British pound & -0.008 & $(0.007)$ & -0.009 & $(0.021)$ & -0.007 & $(0.006)$ & 0.008 & $(0.014)$ \\
\hline Malaysian ringgit & 0.007 & $(0.012)$ & 0.043 & $(0.030)$ & -0.022 & $(0.012)$ & 0.033 & $(0.021)$ \\
\hline Canadian dollar & -0.006 & $(0.004)$ & $-0.035 * *$ & $(0.012)$ & 0.006 & $(0.004)$ & -0.066 & $(0.006)$ \\
\hline Australian dollar & 0.001 & $(0.005)$ & $0.037^{* *}$ & $(0.014)$ & 0.0001 & $(0.005)$ & -0.006 & $(0.009)$ \\
\hline Russian ruble & $0.015 * *$ & $(0.006)$ & $0.131 * *$ & $(0.040)$ & 0.004 & $(0.006)$ & $0.019 * *$ & $(0.009)$ \\
\hline Thai baht & 0.021 & $(0.010)$ & -0.007 & $(0.017)$ & $0.046^{* *}$ & $(0.016)$ & 0.020 & $(0.019)$ \\
\hline Constant & $-4.89 \mathrm{E}-05^{* *}$ & $(1.22 \mathrm{E}-05)$ & $-0.0001 * *$ & (3.01E-05) & $-1.07 \mathrm{E} 05$ & $(1.46 \mathrm{E}-05)$ & $-4.22 \mathrm{E}-05 * *$ & $(1.78 \mathrm{E}-05)$ \\
\hline Observations & \multicolumn{2}{|c|}{780} & \multicolumn{2}{|c|}{165} & \multicolumn{2}{|c|}{266} & \multicolumn{2}{|c|}{349} \\
\hline Adj. R-squared & \multicolumn{2}{|c|}{0.937} & \multicolumn{2}{|c|}{0.878} & \multicolumn{2}{|c|}{0.980} & \multicolumn{2}{|c|}{0.926} \\
\hline
\end{tabular}

Source: Author's calculation.

Note: Standard errors in parentheses. Whole sample: January 1, 2007-March 30, 2013. Period 1: January 1, 2007-June 30, 2008. Period 2: July 1, 2008-June 30, 2010. Period 3: July 1, 2010-March 30, 2013. * Significant at 10\%; ** Significant at 5\%.

We then compare our results with the findings of Frankel and Wei (2007) in which they covered the different period from ours (see Table 5). Not surprisingly, the US dollar's weigh remained the largest in the RMB's currency basket in all periods. But its importance is fading. Compared to 90.4 per cent during period July 2005 to August 2007 in Frankel and Wei (2007), the weight was assigned to the US dollar was around 80 percent in period 
1 and 3. But it increased to 90.1 per cent during the financial crisis period (period 2 in our research). Notably, in our results, more currencies received weights in RMB basket in each of periods than the results in Frankel and Wei (2007), such Singaporean dollar in period 2 and 3, Russian ruble in period 1 and 3 as well as the euro, Japanese yen and Korean won in period 1. It indicates that extent of the RMB pegging to its currency basket is increasingly higher than before. Also, it seems that the PBoC adjusted the weights of component currencies in RMB basket with accordance to external economic environment and possible political pressure.

Table 5. Comparison of our findings with previous study (numeraire currency $=$ SDR)

\begin{tabular}{|c|c|c|c|c|c|c|c|c|}
\hline \multirow{3}{*}{$\begin{array}{l}\text { Sub-period } \\
\text { US dollar } \\
\text { the euro }\end{array}$} & \multicolumn{2}{|c|}{$\begin{array}{c}\text { Frankel and Wei (2007)'s } \\
\text { results } \\
\end{array}$} & \multicolumn{2}{|c|}{ Period 1} & \multicolumn{2}{|c|}{ Period 2} & \multicolumn{2}{|c|}{ Period 3} \\
\hline & $0.904 * *$ & $(0.021)$ & $0.833^{* *}$ & $(0.052)$ & $0.901 * *$ & $(0.021)$ & $0.802 * *$ & $(0.027)$ \\
\hline & -0.006 & $(0.014)$ & $0.063 *$ & $(0.037)$ & 0.000 & $(0.011)$ & $-0.027 *$ & $(0.017)$ \\
\hline Japanese yen & 0.008 & $(0.009)$ & $0.067 * *$ & $(0.014)$ & $0.010 *$ & $(0.005)$ & 0.003 & $(0.008)$ \\
\hline Korean won & 0.002 & $(0.009)$ & $0.051 * *$ & $(0.014)$ & -0.001 & $(0.003)$ & 0.007 & $(0.009)$ \\
\hline Singapore dollar & -0.018 & $(0.021)$ & 0.025 & $(0.045)$ & $0.049 * *$ & $(0.018)$ & $0.052 * *$ & $(0.025)$ \\
\hline British pound & -0.004 & $(0.011)$ & -0.009 & $(0.021)$ & -0.007 & $(0.006)$ & 0.008 & $(0.014)$ \\
\hline Malaysian ringgit & $0.053 * *$ & $(0.015)$ & 0.043 & $(0.030)$ & -0.022 & $(0.012)$ & 0.033 & $(0.021)$ \\
\hline Canadian dollar & 0.003 & $(0.008)$ & $-0.035 * *$ & $(0.012)$ & 0.006 & $(0.004)$ & -0.066 & $(0.006)$ \\
\hline Australian dollar & -0.003 & $(0.008)$ & $0.037 * *$ & $(0.014)$ & 0.0001 & $(0.005)$ & -0.006 & $(0.009)$ \\
\hline Russian ruble & -0.018 & $(0.021)$ & $0.131 * *$ & $(0.040)$ & 0.004 & $(0.006)$ & $0.019 * *$ & $(0.009)$ \\
\hline Thai baht & 0.006 & $(0.010)$ & -0.007 & $(0.017)$ & $0.046^{* *}$ & $(0.016)$ & 0.020 & $(0.019)$ \\
\hline Constant & $9.00 \mathrm{E}-05^{* *}$ & (3.00E-05) & $-0.0001 * *$ & $(3.01 \mathrm{E}-05)$ & $-1.07 \mathrm{E} 05$ & $(1.46 \mathrm{E}-05)$ & $-4.22 \mathrm{E}-05^{* *}$ & (1.78E-05) \\
\hline Observations & \multicolumn{2}{|c|}{382} & \multicolumn{2}{|c|}{165} & \multicolumn{2}{|c|}{266} & \multicolumn{2}{|c|}{349} \\
\hline Adj. R-squared & \multicolumn{2}{|c|}{0.95} & \multicolumn{2}{|c|}{0.878} & \multicolumn{2}{|c|}{0.980} & \multicolumn{2}{|c|}{0.926} \\
\hline
\end{tabular}

Source: Author's calculation and Frankel and Wei (2007)'s findings.

Note: Standard errors in parentheses. Frankel and Wei (2007)'s period: July 22, 2005-August 1, 2007. Period 1: January 1, $2007-J u n e ~ 30,2008$. Period 2: July 1, 2008-June 30, 2010. Period 3: July 1, 2010-March 31, 2013. * Significant at 10\%; ** Significant at 5\%.

Since the PBoC reaffirmed that China would proceed to reform the RMB exchange rate regime and enhance the flexibility of RMB exchange rate on June 19, 2010, it is interesting to find out how the RMB pegged to its currency basket after this policy was announced. Therefore, we divide period 3 (from July 1, 2010 to March 31, 2013) into six sub-periods to find the latest information on the RMB's currency basket pegging regime. Table 6 reports that the US dollar accounted for the largest weight in RMB basket in each sub-period. Singaporean dollar, Japanese yen, the euro and Russian ruble also received weights in some sub-periods, although their weights were much less than the US dollar's weight. We also observe that the weight of US dollar clearly showed a downward trend since 2011. Its weight declined from 87.9 per cent in the first half year of 2011 (sub-period 2) to 73.2 per cent in the first three months of 2013 (sub-period 6). This finding reconfirms that the RMB is no longer tightly peg to the US dollar. It is shifting to a currency basket pegging regime, although other component currencies' weights were adjusted frequently. More interestingly, we find that Singaporean dollar's weight in RMB basket was 13.2 per cent in sub-period 5 and 21.2 per cent in sub-period 6. Singapore's exchange rate regime (Band-Basket-Crawl), which is a typical managed floating regime by referring to a currency basket of its major trading partners and competitors, is similar to China's announced exchange rate regime. It may tell us that Singaporean dollar is playing more important role in RMB basket. By referring to Singaporean dollar, the RMB could indirectly peg to other regional currencies in addition to the major international currencies. In addition, adjusted R-squared increased from 90.9 in sub-period 1 to 97.7 in sub-period 6, although it dropped slightly to 89.2 in sub-period 4. It means that our data is highly fit to this model. In other words, the RMB exchange rate regime is relatively tight currency basket pegging regime. 
Table 6. Estimation of eleven currencies' weights in RMB basket (July 1, 2010 to March 31, 2013, numeraire currency $=$ SDR)

Table 6a.

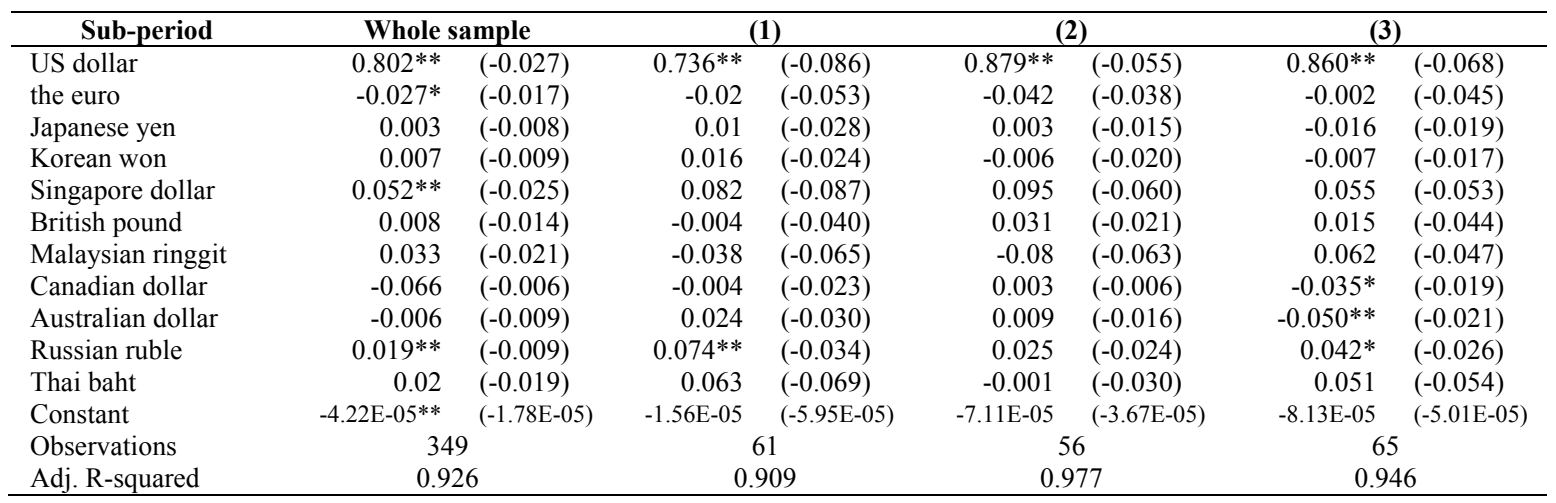

Table $6 b$.

\begin{tabular}{lrlrrrr}
\hline \multicolumn{1}{c}{ Sub-period } & \multicolumn{2}{c}{$(\mathbf{4})$} & \multicolumn{2}{c}{$\mathbf{( 5 )}$} & \multicolumn{2}{c}{$(\mathbf{6})$} \\
\hline US dollar & $0.719^{* *}$ & $(-0.080)$ & $0.775^{* *}$ & $(-0.071)$ & $0.732^{* *}$ & $(-0.098)$ \\
the euro & -0.057 & $(-0.046)$ & -0.005 & $(-0.034)$ & $-0.084^{* *}$ & $(-0.039)$ \\
Japanese yen & $0.053^{* *}$ & $(-0.023)$ & -0.012 & $(-0.024)$ & $-0.048^{* *}$ & $(-0.024)$ \\
Korean won & 0.012 & $(-0.030)$ & $0.061^{*}$ & $(-0.033)$ & 0.009 & $(-0.030)$ \\
Singapore dollar & 0.091 & $(-0.083)$ & $0.132^{* *}$ & $(-0.064)$ & $0.212^{* *}$ & $(-0.096)$ \\
British pound & 0.025 & $(-0.040)$ & 0.054 & $(-0.042)$ & 0.007 & $(-0.029)$ \\
Malaysian ringgit & 0.007 & $(-0.069)$ & 0.041 & $(-0.045)$ & -0.031 & $(-0.060)$ \\
Canadian dollar & -0.022 & $(-0.025)$ & 0.005 & $(-0.024)$ & -0.029 & $(-0.033)$ \\
Australian dollar & -0.003 & $(-0.027)$ & -0.036 & $(-0.026)$ & 0.012 & $(-0.023)$ \\
Russian ruble & 0.004 & $(-0.018)$ & 0.02 & $(-0.021)$ & -0.057 & $(-0.042)$ \\
Thai baht & 0.069 & $(-0.044)$ & -0.014 & $(-0.064)$ & -0.039 & $(-0.047)$ \\
Constant & $-2.47 \mathrm{E}-05$ & $(-4.34 \mathrm{E}-05)$ & $8.20 \mathrm{E}-06$ & $(3.38 \mathrm{E}-05)$ & $-4.26 \mathrm{E}-05$ & $(-4.24 \mathrm{E}-05)$ \\
Observations & \multicolumn{2}{c}{64} & \multicolumn{2}{c}{69} & \multicolumn{2}{c}{34} \\
Adj. R-squared & \multicolumn{2}{c}{0.892} & \multicolumn{2}{c}{0.921} & & 0.971 \\
\hline
\end{tabular}

Source: Author's calculations.

Note: Standard errors in parentheses. (1): July 1, 2010-December 31, 2010. (2): January 1, 2011-June 30, 2011. (3): July 1, 2011-December 31, 2011. (4): January 1, 2012-June 30, 2012. (5): July 1, 2012-December 31, 2012. (6): January 1, 2013-March 31, 2013. * Significant at 10 \%; ** Significant at $5 \%$.

\section{Conclusions}

Since China's authority initiated RMB exchange rate regime reform in 1994, the RMB had been consistently pegged to the US dollar at the rate of 8.28 yuan per unit of the US dollar until 2005 for about ten years. This US dollar pegging exchange rate regime played an important and positive role for China's economic growth during this specific period. But such purely US dollar pegging regime seriously distorted RMB nominal exchange rate from its real exchange rate and accumulated huge trade surplus in China's current account. Therefore, as an integral component of China's financial system reform, a managed floating exchange rate regime with reference to a basket of currencies was adopted by the PBoC since July 2005.

However, de facto exchange rate policy is often different from de jure policy announced by monetary authority. Previous studies find very limited evidence that the RMB is perfectly pegging to its currency basket. Our findings reconfirm it. But our results also prove that the RMB is shifting from the US dollar peg to a currency basket peg regime except for the period of financial crisis. Weight of the US dollar is still the largest in the RMB's currency basket, but its importance decreased steadily. Weights of some currencies in RMB basket are increasing gradually, but not very significantly. Surprisingly, two major currencies: the euro and Japanese yen were not allocated large weights in RMB basket. In contrast, Singaporean dollar received increasing weight in some periods.

China's RMB exchange rate regime is in transitional period from single currency pegging to currency basket pegging. In the long run, China should adopt more flexible exchange rate regime in order to establish a table and resilient financial system. Compared to the single currency pegging regime and free floating exchange rate regime, currency basket pegging regime probably is the optimal exchange rate regime for China to adopt as a transitional measure. It seems that the PBoC doesn't have an explicit and long-term approach in how to allocate weight to each 
of component currencies and adjust the composition of RMB basket so far. So we could not label current RMB exchange rate regime as a currency basket pegging regime. But it is moving toward this direction.

\section{References}

Cheung, Y., Ma, G., \& McCauley, R. (2010). Renminbising China's foreign assets. Hong Kong Institute for Monetary Research's working paper, No. 16/2010.

Cui, Y. (2012). Re-testing Chinese RMB's exchange rate regime: US dollar pegging vs. currency basket pegging. GSTF International Journal of Law and Social Sciences, 1(1), 96-101.

Frankel, J. (2009). New estimation of China's exchange rate regime. Pacific Economic Review. http://dx.doi.org/10.1111/j.1468-0106.2009.00454.x

Frankel, J., \& Wei, S. (2007). Assessing China's exchange rate regime. Economic Policy, 51, 575-614. http://dx.doi.org/10.1111/j.1468-0327.2007.00185.x

Frankel, J., \& Wei, S. (2008, September). Estimation of de facto exchange regimes: Synthesis of the techniques for inferring flexibility and basket weight. IMF Staff Papers. http://dx.doi.org/10.1057/imfsp.2008.18

Frankel, J., \& Xie, D. (2009). Estimation of de facto flexibility parameter and basket weights in evolving exchange rate regimes. NBER Working Paper, Series 15620.

Funke, M., \& Gronwald, M. (2008). The undisclosed renminbi basket: Are the markets telling us something about where the renminbi-US dollar exchange rate is going. The World Economy. http://dx.doi.org/10.1111/j.1467-9701.2008.01141.x

$\mathrm{Hu}, \mathrm{X}$. (2010). A managed floating exchange rate regime is an established policy. Bank for International Settlements Review, 96/2010.

Ito, T. (2007). The influence of the RMB on exchange rate policy in other economies. Peterson Institute for International Economies Conference: China's Exchange Rate Policy.

Jen, S. (2005). Chinese RMB basket still a mystery. Global Economics Forum. Retrieved from http://www.morganstanley.com/views/gef/archive/2005/20050819-Fri.html\#anchor1

Kanamori, T., \& Zhao, Z. (2006). The renminbi exchange rate revaluation: Theory, practice and lessons from Japan. ADBI Policy Paper, No.9.

Kuroda, H. (2004). The "Nixon Shock" and the "Plaza Agreement": Lessons from Two Seemingly Failed Cases of Japan's Exchange Rate Policy. China \& World Economy, 12(1), 3-10.

Liu, X., \& Fan, C. (2010). The model and empirical estimation of the optimal flexibility of RMB exchange-rate regime: A study based on the price-stabilization. Frontiers of Economics in China. http://dx.doi.org/10.1007/s11459-010-0010-7

Ma, G., \& McCauley, R. (2008). The evolving east Asian exchange rate system. Seminars of the Hong Kong General Chamber of Commerce.

Moosa, I. (2008). Exchange rate regime verification: Has China actually moved from a dollar peg to a basket peg. Economia Internazionale.

Moosa, I. (2008). Forecasting the Chinese Yuan-US Dollar exchange rate under the new Chinese exchange rate regime. International Journal of Business and Economics, 7(1), 23-35.

Obstfeld, M. (2007). The renminbi's dollar peg at the crossroads. Monetary and Economic Studies.

Ogawa, E., \& Shimizu, J. (2006). Progress toward common currency basket system. The $5^{\text {th }}$ Asia Pacific Economics Forum.

Qin, F. (2009). The evolution of renminbi exchange rate regime and its policy implications. China Review.

Shah, A., Zeileis, A., \& Patnail, I. (2005). What is the new Chinese currency regime? ePubWU Institutional Repository's working paper.

Sun, L., Qin, P., \& Zhou, Y. (2008). Thirty-year history of RMB exchange rate reform and challenge. World Economic Outlook, 9, 9-20. (in Chinese)

Thierry Apoteker Consultant (TAC). (2005). Assessing the composition of the Chinese currency basket. Retrieved from http://www.tac-financial.com/publ/yuan\%20-\%20200509.pdf

Notes 
Note 1. In October 2010, Brazilin Financial Minister initially said: "we're in the midst of an international currency war", and "this threatens us because it takes away our competitiveness".

Note 2. Japan's the new government (Abe administration) adopted easing monetary policy and loose fiscal policy aimed at curbing the decades-long deflation. Since November 2012, Japanese yen has depreciated considerably by more than 20 per cent until June 2013.

Note 3. The PBoC stated: "in view of the recent economic situation and financial market developments at home and abroad, and the balance of payments (BOP) situation in China, the People's Bank of China has decided to proceed further with reform of the RMB exchange rate regime and to enhance the RMB exchange rate flexibility". See the PBoC's official website: http://www.pbc.gov.cn/publish/english/955/2010/20100622144059351137121/20100622144059351137121_html

Note 4. Zhou Xiaochuan, the governor of the $\mathrm{PBoC}$, informally elaborated the principle and candidate currencies in the RMB's currency basket when he gave opening remark at the inauguration ceremony of the PBoC's Shanghai headquarter in Shanghai on August 9, 2005.

Note 5. Frankel (2009) re-tests the RMB basket by using upgraded Frankel and Wei (1994)'s economic model (adding a new variable). But only four major currencies are included into RMB basket.

Note 6. Currency value of the SDR is determined by summing the values in U.S. dollars, based on market exchange rates, of a basket of major currencies (the U.S. dollar, Euro, Japanese yen, and pound sterling). Based on their roles in international trade and finance, On November $15^{\text {th }}, 2010$, IMF adjusted the weight of each currency: USD $41.9 \%$, EUR $37.4 \%$, GBP $11.3 \%$ and Yen $9.4 \%$.

Note 7. Frankel and Wei (2007) explained in details why they used SDR as a numeraire rather than others like Swiss franc.

\section{Copyrights}

Copyright for this article is retained by the author(s), with first publication rights granted to the journal.

This is an open-access article distributed under the terms and conditions of the Creative Commons Attribution license (http://creativecommons.org/licenses/by/3.0/). 